\title{
The Nigerian Extractive Economy and Development
}

\author{
Murtala Chindo* ${ }^{\mathrm{a}}$, Ali I. Naibbi ${ }^{\mathrm{b}}$, Abubakar Abdullahi ${ }^{\mathrm{c}}$
}

\author{
a IBB University Lapai, Nigeria \\ b University of Portsmouth, United Kingdom \\ c Federal University, Kashere, Nigeria
}

\begin{abstract}
Nigeria is a resource-rich country and has become extraordinarily dependent on the oil sector, which accounts for over 90 per cent of exports and government revenues, and contributes up to one third of the GDP (Gross Domestic Product). Evidences have shown that Nigeria's resource wealth has not translated into meaningful development. For example, while other countries realised positive outcomes from mineral-based developments, Nigeria's poor state of development is assumed to be a product of the pathologies that are collectively known as the 'resource curse'. This paper examines various literatures about the resource curse thesis by focusing on the experience of Nigeria, Africa's largest oil and gas producer and exporting country. The result shows that corruption, government complacency, the Dutch disease, lack of public accountability, neglect of education and excessive external debt/borrowing overhang are all hampering the development goals of the country. Whilst the measurements that support this conclusion were made at the national level, this paper opined and called for the Nigerian resource curse measurements to be looked at from the local scale (communities), where the resource economy hits the ground.
\end{abstract}

Key Words: Development, Nigeria, Oil, Resources, Resource Curse, Minerals.

Article Info: Received: May 28, 2014; Revised: November 5, 2014; Accepted: November 10, 2014; Online: November 30, 2014.

\section{Introduction}

The Nigerian state is largely dependent on mineral rents; from the royalties, levies and taxes paid by transnational oil companies, and on the profits made from equity stakes in the numerous investments with multinational companies. What this oil wealth has brought for the past 50 years and will possibly bring in

\section{* Corresponding author}

Address: Department of Geography, IBB University Lapai, Nigeria.

Email:murtalachindo@gmail.com 


\section{M. Chindo et al.}

the future is a question of intellectual debate. As a geographer, the questions that are of interest are: as Nigeria exploits and expands its resource wealth, what are the processes and inter-relationships through which resources will be developed and what impact will these have at different geographical scale from national to local scale? The expansion of resources should ideally guarantee a certain level of prosperity, but such additional wealth can be a curse as much as a blessing. This assessment is set against the evidence underscoring Nigeria's lagging behind in translating oil wealth into economic prosperity. Many scholars (such as, Auty, 1993; Ross, 2003; Sachs and Warner, 1999) have advanced explanations on why Nigeria and other resource-rich developing nations failed to maximise the blessings of their resource wealth. This phenomenon, commonly known as the 'resource curse thesis' or 'paradox of plenty', is captured in a large body of theoretical and empirical studies pioneered by Auty (1993). Simply, resource curse refers to the paradox where countries that have resources (such as minerals in solid, liquid or gas state) in abundance tend to experience low economic growth and even worst development outcomes. Thus, the broad objective of this paper is to pull together 'resources' and 'development' literature from different perspective, and situate Nigeria within these discourses.

In order to achieve the above objectives, the paper is structured in the following order. Section 2 explains Nigeria's overdependence on oil revenue and the contribution of non-fuel minerals to the national economy. The relationship between resource wealth and development is contained in section 3, followed by an examination of 'mineral economies' and how their mineral wealth affects their national economy. Section 4 elucidates the resource curse phenomenon, with particular emphasis on Nigeria as a resource-cursed economy and where the missing link lies. The conclusion calls for an examination of the resource curse theory at the local scale to identify more detailed gaps in knowledge.

\section{The Nigerian Extractive Economy}

The political economy of Nigeria is based on extractive industries (Orogun, 2010). Major resources found in Nigeria include petroleum, natural gas and solid minerals. Nigeria produces 21.2 per cent of Africa's crude oil ahead of Libya, Egypt, and Algeria. Oil from Nigeria accounts for 2.6 per cent of global production (BP, 2010:8), and the country is ranked the world's 13th largest producer of crude oil (USEIA, 2013). The discovery of substantial hydrocarbon reserves in the deep water offshore is expected to increase the reserve base from 37.2 to 40 billion barrels by 2020 (USEIA, 2013; Premium Times, 2014). As figure 1 illustrates, Nigeria currently produces an average two million barrels per day of OPEC's production, compared to less than 1.5 million barrels at the peak of the Niger Delta oil conflict in 2009. With the resumption of shut-in onshore production and relative peace in the Niger Delta, crude oil production has risen to about 2.5 million barrels per day (USEIA, 2010). Nigerian onshore oil reserves are found in the South-southern region, known as the Niger Delta, is an area of vast area of creeks and waterways, with a surface area of about 112,110 square kilometres (UNDP, 2006). Offshore oil reserves are in the Bight 


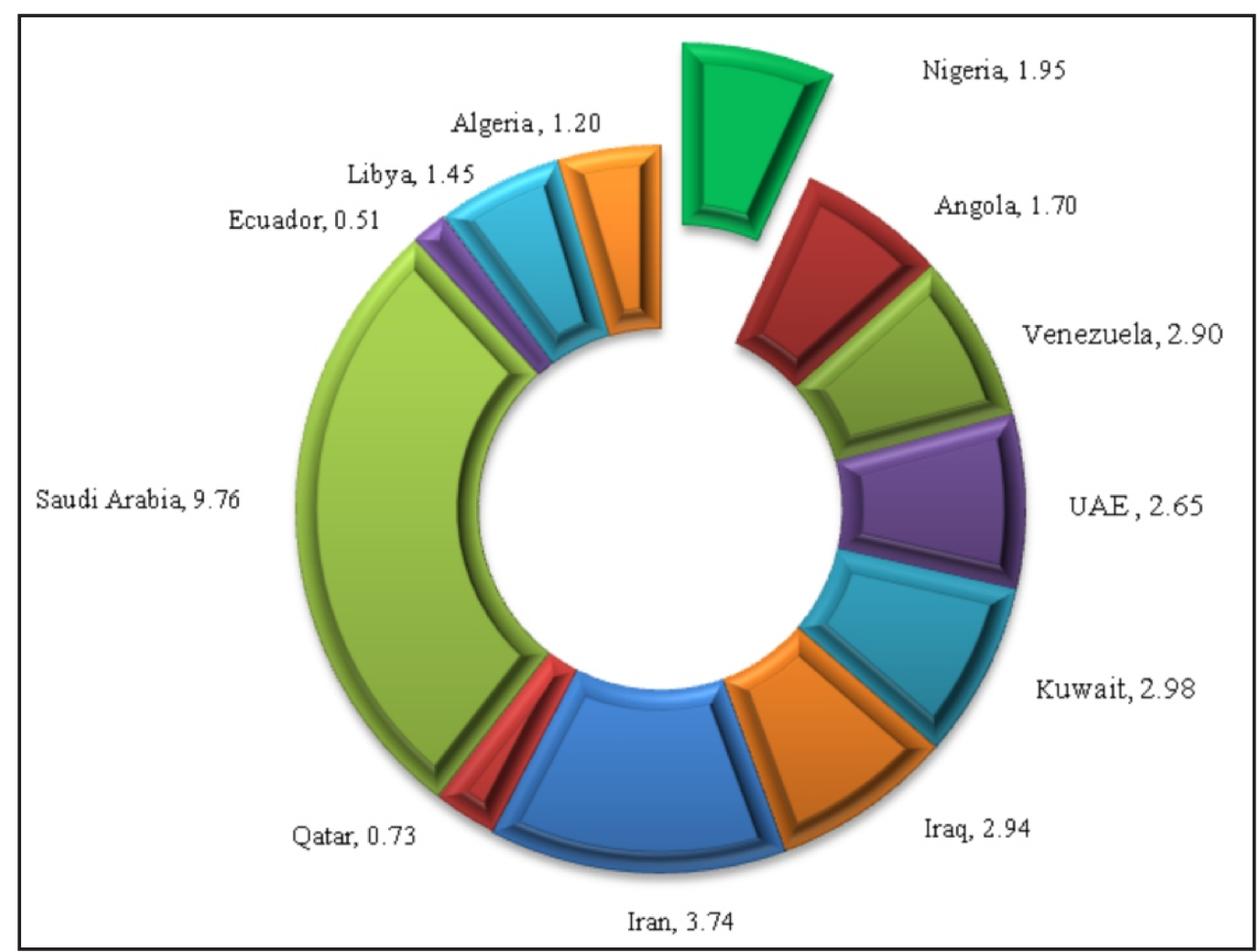

Figure 1. Average daily crude oil production from OPEC countries (Data source from OPEC, 2013).

of Benin, the Bight of Bonny and the Gulf of Guinea. Oil exploration activities in the Niger Delta are currently focused in the deep and ultra-deep water, with some interest in the Chad, Bida and Sokoto basins, to determine the prospect of oil discovery in Northern Nigeria (Abubakar, 2014; NNPC, 2014; Obaje et al., 2004; Obaje et al., 2004; Vanguard, 2014) (Figure 1).

According to the Revenue Watch Institute (2010), the Nigerian economy, which depends on oil exports has grown extraordinarily in recent years. For example, while from the early 1970s to 2010, the total earnings from oil stood at just over US $\$ 600$ billion, with Nigeria's petroleum exports valued at US $\$ 94.6$ billion at the end of 2012 alone (OPEC, 2013). Prior to the economic downturn of 2008, the national income had risen significantly, with external reserves reaching an all-time high of US\$60.1 billion in 2008 (Revenue Watch Institute, 2010). Despite the huge revenue earnings in the country, the vast majority of the Nigerian people have not benefitted from this legacy of wealth as can be seen in the later part of this section.

In addition to oil wealth, Nigeria has an estimated 5.3 trillion cubic metres (TCM) of gas reserves, making it the world's seventh largest holder of natural gas reserve and the largest in Africa (USEIA, 2010). Apart from natural gas, about two-third of oil fields - associated gas (AG) is currently flared (12.5 per cent of the world's total) because of lack of infrastructure to utilise the flared gas. Any expansion of Nigeria's liquefied natural gas (LNG) infrastructures (pipeline development), and the strengthening of gas-flaring policies would reduce gas flaring in the immediate future, and accelerate gas utilisation, both for export market and domestic use. 


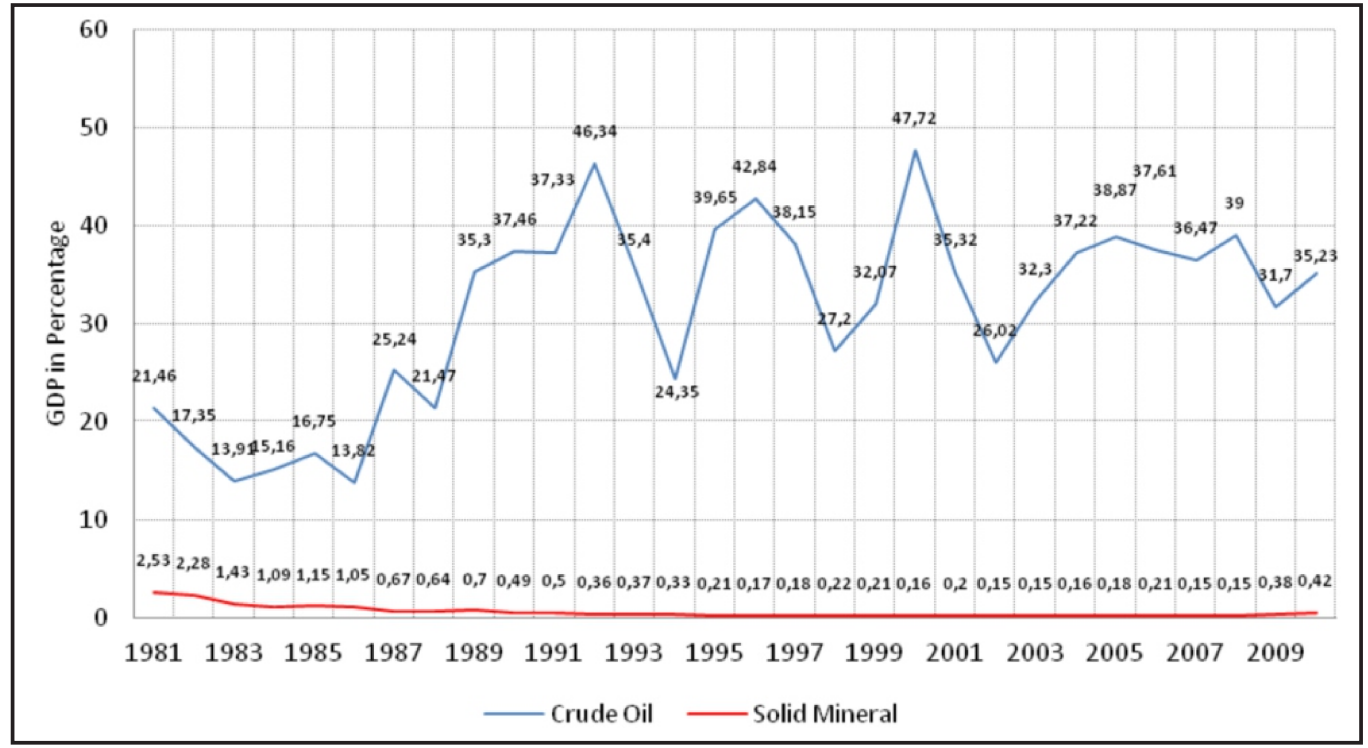

Figure 2. Contribution of crude oil and solid minerals to the GDP from 1981-2010 Source: Data from NBS $(2009 ; 2010)$.

Apart from oil and gas, Nigeria is endowed with solid mineral wealth such as gold, iron ore, columbite, coal, limestone, oil sands, tin, barite among others (see, for example, Obaje, 2009). Solid minerals, unlike oil, are found across the country; while some of them are of commercial value, others are too small to exploit profitably under current market and technological conditions. Yet, other unconventional oil resources, such as oil sands, are awaiting investment (Ayoade, 2007; Meyer et al., 2007; MSMD, 2008). Davenport (2010) estimated that the expansion of mining has the potential to contribute about 15 per cent to Nigeria's GDP by the year 2015. This is an overly optimistic estimate considering the current poor performance of the sector within the economy. As figure 2 illustrates, this sector, unlike oil, is undeveloped, non-productive, and currently contributes less than 0.5 per cent to Nigeria's GDP (NBS, 2013). For example, Nda-Isiah (2013) claimed that the amount of revenue the country loses from gold alone is about N4 trillion (US\$25 billion) per annum, which is roughly equivalent to the annual national budget (Figure 2).

Usually, the combination of Nigeria's oil and gas revenues and solid minerals potential would be considered a 'blessing' to the nation. Unfortunately, the blessings have instead become a curse, because Nigeria's development indices radically differs from the promises. A look at some measures of economic and social development supports the above statement. The poverty rate (measured against US $\$ 1$ per day) continues to rise, accounting for over 60 per cent of Nigeria's estimated 170 million people, 43 per cent lack clean water and good sanitation and infant mortality is among the highest in the world (NBS, 2008; UNICEF, 2014). Furthermore, the 2013 UNDP Human Development Index ranked Nigeria below countries like Uganda, Cameroon, Ghana, Gabon, Togo and Congo. Despite the vast mineral wealth and human resources, 68 per cent of Nigerians live on less than US $\$ 1.25$ a day (UNDP, 2010:162). This suggests that the number of poor people in Nigeria is more than the combined 90 million population of the other 10 West African countries, excluding Ghana and Cote d'Ivoire. 
Nigeria's energy sector continues to dwindle over the years - even with abundant energy resources - and the crisis has defied solution. Electricity supply is erratic and of poor quality (Odularu and Okonkwo, 2009). By the end of 2013, the total power generation capacity was less than 4,000 megawatts (MW), meaning per capita energy consumption was just 135 kilowatt hours $(\mathrm{kWh})$ per person - less than that of Ghana, Senegal, Angola and Kenya (Research and Markets, 2011; Sambo, 2009). The huge deficit meant that the majority of the population live far below the 4,000 kWh levels required for achieving a decent standard of human existence (UNDP, 2010). Around 50.6 per cent of the 168.8 million people are without access to electricity, while the remaining 85 million receive low quality or an irregular supply (Moss, 2014). Thus, it will be difficult and expensive for Nigeria to sustain its economic growth, drive policies towards diversification, energise human development process, attain the Millennium Development Goals (MDGs) and encourage investors, without making reliable and affordable energy available.

The description above of the coexistence of vast wealth in natural resources, weak economic performance and weak human development as exemplified by high personal poverty is regarded as the 'resource curse' or the 'paradox of plenty', that afflicts Nigeria (Auty, 1993).It is therefore not surprising that the 'Failed States Index' ranked Nigeria as the 16th most failed nation in the world in 2013, because of the country's weak internal security and the government's failure to perform basic development functions (The Fund for Peace, 2014). These rankings show a worrying combination of high levels of poverty and high levels of risks. The risk might even be higher in solid minerals because they require large amounts of capital with long payback periods, and projects can operate for decades. Resource investments are made taking into account potential rewards against possible risks. Apart from operational risks (exploration, mining, production and reclamation), business-related risks, carbon emissions and social and legal factors such as government effectiveness and communities' affects investment decisions (see, for example, Bhappu and Guzman, 1995; Costa Lima, 2006; Esteves, 2008; Morgan, 2002; Topal, 2008).

In addition to the above uncertainties, the world now faces energy dilemma in meeting the future challenges of energy security and climate change (Bradshaw, 2013). With countries working at achieving their carbon emission targets and discussing alternative and renewable sources of energy (Bradshaw, 2013), the predictions for the future of oil cannot be all positive, and this is a catastrophe for Nigeria whose revenue depended on it. Unlike Nigeria, Saudi Arabia and the United Arab Emirate are tackling the reality of oil volatility through economic diversification, such as manufacturing and tourism (Aldagheiri, 2008). Other OPEC countries, notably Qatar is planning in and for a situation of plentiful oil and gas reserves (see Hvidt, 2013). If lessons are to be learnt from the 2008 oil price shock, Nigeria should pay greater attention to diversifying its economy and depend less on oil revenue, while strengthening the tax system in a similar manner achieved by non-oil producing countries. 


\section{Mineral Resources and Development}

Mineral resources are by nature the most common form of non-renewable resources that are extracted as primary products, for example, metallic minerals (lead, zinc, iron ore, diamond, gold), hydrocarbons in solid, liquid and gas states of matter (bitumen, oil, gas) and aggregates/industrial minerals (gypsum, limestone, granite, phosphate). Adequate, affordable and secure access to mineral resources is regarded as the lifeblood of a modern society (Bradshaw, 2005). This means minerals should be a blessing provided by nature to be used to better the lot of a nation and its citizens.

Naturally, the key drivers for resource demand are population and economic growth, with associated urbanisation, rising standards of living, construction activity and infrastructure, metals and energy-intensive manufacturing and industrialisation. It is estimated that emerging countries will need more mineral resources to fuel their development and infrastructure growth. For example, the BRIC nations (Brazil, Russia, India and China) alone are expected to consume about 121 per cent of oil, 140 per cent of aluminium and 105 per cent of copper by 2015 (Friedland, 2008). Similarly, advances in technology are related to the increase in demand for platinum. Diesel/hydrogen cars are being considered for the future to reduce carbon emission and reduce the rate of fuel consumption. To realise this goal, the demand for platinum as a raw material is on the rise, resulting in increasing prices.

Another important key driver for resource demand is the global agenda for development such as the MDGs (e.g. Warner and Alexander, 2005). To meet these goals in an era of declining conventional oil reserves, there is the requirement for huge supplies of mineral resources, the provision of clean water, sanitation and healthcare, transport and telecommunications services, and power for heating, cooking and industrialisation (Organisation for Economic Co-operation and Development (OECD) (OECD/IEA, 2010). Consequently, new frontiers like ultra-deep water and the Arctic, or unconventional and dirtier forms of fossil fuels such as the oil sands, oil shale, tight gas and shale gas are being developed. The result is growing demand that is fuelling the dramatic increase in greenhouse gas emissions that causes climate change.

Unlike the oil boom periods in the past, growth in mineral demand has shifted geographically in favour of the developing countries. Mineral supply to non-OECDs has increased tremendously as economic growth in these countries is more heavily reliant on mineral resources than is the case in OECD countries. China, India and the Middle East are identified as the main locus of demand, because their economies are currently in a "resource-intensive growth phase" (United Nations Centre for Trade and Development (UNCTAD), 2007:88). During the cyclical era of mineral boom, exporting countries benefit immensely from high mineral prices, and market capitalisation of mining companies has followed the same trend - i.e. looking for opportunities to expand production and intensify exploration. Those countries whose economies depend on their mineral wealth have the prospects of generating higher revenue to finance their societies. For example, Australia benefitted from mineral export, earning AUD59.2 billion in 2006 alone (ICMM, 2007).

According to Mahtani (2008:1), there is a "new scramble for Africa's 
resources" ranging from conventional to unconventional oils by small start-up companies to multinationals. The new frontiers for oil are Ghana, Uganda, Niger and the discovery of oil sands in Madagascar, Congo and Nigeria corroborate Mahtani's (2008) assertion. In 2007, China offered a loan of US $\$ 5$ billion to DRC for the development of its infrastructure in return for cobalt and copper. In reaction to this rush for finite resources and the accompanying unfolding energy crisis, in 2007 the G8 summit put global energy security and climate change at the top of international political agenda. The next section considers theoretical background for situating Nigeria as a mineral economy.

\section{Mineral-Dependent Economies}

The definition of a mineral economy is not merely dependent on the amount of resources available to a country, but also on the contribution of such resources in macro-economic terms. Ahrend (2005:4) define resource-based economies as countries whose mineral revenues account for more than 10 per cent of GDP and 40 per cent of exports. This definition fails to take into account the diversity and heterogeneity of countries. Some countries largely depend on mineral exports, which contributes less significantly to their GDP. The World Bank (2004) classify resource-rich countries as those in which extractive industries account for, or are expected to account for, more than 50 per cent of government revenues. This paper relies on the International Monetary Fund's (IMF) definition, which defines mineral economies on the basis of: 1) the average share of hydrocarbon, and/or mineral revenues in total fiscal revenue of at least 25 per cent during the previous three years; and 2) on an average share of hydrocarbon and/or mineral export proceeds in total export proceeds of at least 25 per cent during the previous three years (Extractive Industries Transparency Initiatives (EITI), 2005:4). This definition suggests that almost all African countries are either mineral economies, emerging mineral economies or economies with significant mineral potential.

Nigeria, together with Botswana, Angola, South Africa, Liberia and Saudi Arabia fall into the category of mineral economies, because each of these countries economy squarely relies on resource revenue. For example, in Nigeria and Saudi Arabia, the petroleum sector accounts for 45 per cent of GDP and 90 per cent of export (United States Energy Information Administration (USEIA), 2009). The hydrocarbon sector in Libya accounts for 70 per cent of the GDP, 93 per cent of government revenues and 95 per cent of export earnings (Edwik, 2007). Emerging mineral economies including Tanzania, Niger, Ghana, Mali and Democratic Republic of the Congo have high-value oil, gold, copper and diamond reserves, but are yet to realise the full potential of their resources.

The development literature suggests that resource-rich and mineral economies should, under normal situations, have some obvious advantages over resource-poor countries. First, revenues earned through mineral exports can generate wealth, thus allowing the purchase of essential goods and provision of services to the people. Second, processing of these minerals into finished or semi-finished goods can promote industrialisation with import substitution and competitive exports. Third, revenues from mineral resources can be used to finance human and physical development. On the contrary, and unfortunately, 
the experience of these countries over the past several decades shows dramatical drop in path to development (Auty, 1994; Ahrend, 2005). This is particularly the case in the developing countries where countries with rich minerals suffers from a low level of human and capital development. The contribution of resources to development in these countries has become subject to intense enquiry, which is a reflection of the complex issues surrounding mineral extraction, the challenge of maximising benefits, and the sustainable development of particularly local communities. The next part of this paper highlights the transition from resource wealth to resource curse.

\section{The Resource Curse Phenomenon}

According to Auty (2001a), resource endowment can bring a huge wealth to countries and can be a valuable development asset. Considering the rising mineral prices and increasing revenue to resource-rich countries, this view was challenged, as it was observed that resource-rich countries grew more slowly than resource-poor countries. In this case, this paper simplifies the various opposing arguments that resources are a curse rather than a blessing into 'conventional' and 'alternative' views.

Prior to 1980s, the conventional view, using modernisation theory, argues that large revenue from mineral wealth through rents should generate substantial wealth for the economy, which would translate to economic prosperity, poverty reduction and service delivery, just like the path taken by the developed nations. Furthermore, it explains that mineral reserves can be mined profitably as part of a country's stock of natural capital, along with agricultural land, forests, and other natural resources. Proponents of this view, known as the big push theorists (see, for example, Rosenstein-Rodan, 1943), suggested that mineral endowment would industrialise the developing countries based on revenue windfalls from extractive activities. Likewise, Rostow's (1960) third of the 'five-stage development model' argued that the presence of abundant natural resources would allow developing countries to 'take off' (a transitional stage) similar to Britain's course to development. No doubt, resources have historically played a vital role in the economic success of resource-rich countries, such as in Canada, Australia, Norway and the United States. However, the global economy has changed significantly since the nineteenth century, and assumptions based on historical analogy that all resource-rich countries will take the same path to development are misleading (Power, 2002).

Empirical studies undertaken by the International Council on Mining and Metals (ICMM), United Nations Conference on Trade and Development (UNCTAD) and the Overseas Development Institute (ODI) (2006), among others, established that mineral extraction provides economic growth and poverty eradication opportunities to countries that are at their early stages of development. This was based on case studies where the mineral industry is bringing about economic prosperity. Surely the above are examples of countries that have managed to avoid the curse. For example, Ross (2001:62) admitted that: "some states with large extractive industries - like Botswana, Chile and 
Malaysia - have overcome many of the obstacles ....and implemented sound propoor strategies". Other similar instances include Indonesia (Temple, 2001) and Norway (Wright and Czelusta, 2002). Likewise, emerging oil economies such as Angola,Uganda, Peru, Tanzania and Ghana are likely to benefit from their resources if they can learn from Nigeria, Libya and Iraq the kind of challenges that confront African countries that seek to exclusively depend oil or other mineral wealth as a catalyst for fostering economic growth and development.

The alternative view is more negative about the ability of mineral revenues to promote economic prosperity. While Richard Auty was the first to use the term 'resource curse' in economic literature to show why resource wealth hinders economic growth and development, Sachs and Warner (1995) are among the first authors to use cross-country evidence for the resource curse phenomenon. An earlier study by Auty (1990) found that per capita income of non-mineral producing nations is two to three times higher than that of the mineral economies. The publication of their evidence heralded the emergence of an extensive body of literature that sought to explain their findings (see for example, Auty, 2001a,b) in different perspectives (see for example, Brunnschewiler, 2008; Stevens, 2003). Stevens (2003) has questioned the robustness of the findings of Auty (2001a) on the basis of the definition of resource-intensity, and the time period chosen for their analysis. The resource curse thesis, however, offers a diverse set of explanations covering, amongst others, terms of trade effects, Dutch disease (the decay and diminishing contribution of other sectors other than oil in the economy), internal conflict, human rights, debt overhang, institutional quality, corruption and rent-seeking behaviour.

Conversely, modern analysts such as Watts (2008) and Orogun (2010) considered the advent of oil as leading to weakening nascent democratic institutions, repressing political policies, poor and opaque public finance and corruption by elites in 'Petrostates' (Watt, 2008). Nigeria, Venezuela, Sierra Leone, Angola, and Niger are common examples of mineral economies associated with poor economic growth, conflict and under-development. Thomas Friedman; New York Times columnist, having studied crude oil prices in relation to freedom and political powers in Iran, Iraq, Venezuela, Nigeria and Russia for three decades, identified a First Law of Petropolitics. In this law, Friedman argued that: "the higher the average global crude price of oil, the more free speech, free press, fair elections, an independent judiciary, the rule of law, and independent political parties are eroded" (Friedman, 2006:29).

A similar assertion was made earlier by Auty (2004:13): "oil wealth is and can be often ill-managed, but as countries run out of oil they are increasingly becoming democratised and open to free trade and develop superior prospects for economic growth and sustainability" Bahrain, for example, is the first Gulf State to overhaul its labour laws in accordance with international labour standards. The current unrest, however, may be linked to the Kingdom's relatively small oil and gas production revenue that is insufficient for public spending without raising taxes, and the ruling class was seen amassing the dwindling wealth at the expense of the majority of the country's 1.3 million inhabitants. 


\section{Rationale for the Nigerian Resource Curse}

The transition to resource curse can be broken into behavioural, state-centred and social capital perspectives (Rosser, 2006) - Nigeria incorporates each of these. The behaviouralist perspective places blame on the attitude of rentseeking political actors in the context of natural resource wealth (UNDP, 2006). The concentration of capital ownership among political elites reproduces social inequalities between those inside the elite (mostly politicians) and those outside it. This explains why the already existing income inequalities tend to expand (Auty, 1994), as in the Nigerian situation, Omeje (2006:2) referred to it as an 'alliance of dominant social class forces', which include top politicians, retired military, technocrats and international capital, that contribute to the spate of military coups and political instability and have continued to dictate and share power - neglecting their responsibilities to the people. Political instability has hampered long-term reform and planning either by the same government or succeeding governments. Nigeria since its independence in 1960, has had 14 governments, out of which eight were as a result of military coups. Shamsuddeen (2007) for example, blames the curse on the four decades of dictatorial military rule because their style of leadership gives limited room for participation in governance. It was only from 2007 that democratically elected government transfers power to another elected government since independence. However, the 'dominant class force' or 'rentier elites' continues to dictate and share power amongst themselves (see Ebohon, 2013 on how government bureaucracy has turned into a rentier class).

Based on a mixture of cognitive, societal, and institutional arguments, statecentred explanations elucidate how over-reliance on resource rents can inhibit the development of sound economic policies, increase public spending through ill co-ordinated decisions, and result in less accountability and transparency, corruption and wastes (Auty, 2001b). A notable example of waste is the accumulation of physical capital coinciding with the periods of two major oil price shocks between 1973 and 1980. Public investment, the majority owned by government, has increased by about seven per cent of the GDP during the shock period. However, more than half of the investments are consistently wasted due to over-investment and poor productivity.

The major problem in Nigeria, according to Sala-i-Martin and Subramanian (2003:17) is that "oil revenues that the government gets are regarded as manna from heaven which tends to corrupt institutions and lower the long-term growth prospects". The state-centred explanation also contends that oil extraction generates large streams of foreign exchange, and these large flows become the basis for patronage that supports dictatorship and autocracy, and less accountability to the societies they govern. Governance failure and complete lack of public accountability can be the main reasons for the failure of resource wealth to translate into development. Instead, Ross (2001) argues, part of the revenue surplus is used in suppressing opposition through tax policies and surplus campaign spending. Further, Ross (2001) believe that the reduction or elimination of taxes by governments is a strategy of making people less likely to hold the government accountable to them.

The social capital perspective argues that access to and the struggle for 
ownership of natural resources creates conflicts (Jensen and Watchenko, 2004). Jensen and Watchenko (2004) make a further suggestion that the concentration of power among the few makes it rational for the opposition to pursue power through extra-constitutional means.

Also, it gives rise to agitation over the acquisition of a fair share of the natural resources revenue. Similarly, separatist tendencies may arise with the feeling that resources revenue has been siphoned from the producing region to the capital or abroad. These views have in part led to conflict and instability in the Nigerian Niger Delta (Orogun, 2010; Watts, 2008). The Niger Delta in contrast with the oil richness of the region is regrettably, one of the annoying examples of the resource curse. The region suffers "administrative neglect, crumbling social infrastructure and services, high unemployment, social deprivation, abject poverty, filth and squalor, and endemic conflict" (UNDP, 2006:9). Current mining activities around the country disclose the possibility of heightening the Niger Delta crises because of the centralisation of the initial extractive activities, and the lack of consultation with the communities (Chindo and Bradshaw, 2013).

Evidence exist to show that commodity price volatility has a negative effect on the economic growth of mineral economies (Santos, 2010). Instead of saving the excess revenue during the boom period for the future, the boom cycle encourages governments to initiate immediate, often short-term, unrealistic expenditures. This leads to a spending spree including embarking on high-cost infrastructure projects (often called white elephant projects) that may be financed by external debts. More importantly in this context, Palley (2006:5) argued that "making unproductive investments and unplanned spending is the vehicle for corruption and influence peddling.

The net result is loss of fiscal discipline that contributes to inflation, the build-up of external indebtedness, and the development of cultures of corruption". This way, macroeconomic scholars (such as Davis, 1995) believe the Dutch disease sets in, because the additional wealth generated induces exchange rate volatility which, if uncontrolled, harms domestic production in the long-run.

As a result of rent-seeking activities and mentality, the state largely neglects its responsibilities to the people in "preference for the interest of international capital and the self-seeking interests of state officials and the hegemonic elites" (Omeje, 2006:2). Furthermore, Ko (2014) argued that tremendous oil wealth has over the years impeded or dismantled true federalism in Nigeria. For example, Nigeria's federal structure was instituted as a way of balancing economic and political freedom, such that: 1) there is equal and fair distribution of national wealth irrespective of where it is located, 2) each region from the six geopolitical zones (north-central, north-east, north-west, south-east, south-south, south-west) is not disadvantaged in the political process and in public policy, 3) responsibilities are shared equally in the creation of national income and 4) no region with minority population is suppressed from majority rule or disenfranchised from political and economic processes (Onoh,1983). The overdependence on oil resource has dismantled the above traits of federalism and is currently characterised by conflict, inequality in the allocation and distribution of national wealth, centralised power among rentier elites and repression. This situation was also was corroborated by Obi (2007:10): 
"Within Nigeria, oil has featured prominently in the politics within and between the various tiers of the federal government, particularly as it relates to the principles for controlling and sharing the oil wealth between the oil producing and non-oil producing parts of the country. This touches upon issues of inter-ethnic relations and the distribution of power in a multi-ethnic federation. The case of the escalating violence in the oil-rich ethnic minority Niger Delta region of Nigeria, where the conflict over the control of oil is assuming the dimension of an incipient insurgency, aptly captures some of the fall-outs from disputes over the sharing of oil revenues".

\section{Solutions to the Resource Curse and the Missing Link}

A number of solutions for transforming the resource curse into a blessing have been proffered. Several scholars have focused on sound economic policy changes (Auty, 1995), diversification (Veit et al., 2011), the creation of stabilisation funds (Santos, 2010; Skancke, 2003), introduction of neo-liberal economic policies (UNDP, 2006) and the reform of governance and social structures (McPhail, 2008). Other scholars have called for international intervention to reduce the curse (Bannon and Collier, 2003:10), and Auty (2004: 46) has supported the use of international certification processes, such as the Kimberley Process Certification Scheme. According to Müller (2010), the institutionalisation of best practices such as the EITI is a means to overcome lack of transparency and corruption in the management of resource wealth.

While the above suggestions proffered can foster development in Nigeria, they tend to centre at the national level and at the point when the resource is fully operational (see for example, Auty, 1997; Collier, 2007), neglecting the resource producing communities that bear the brunt of the curse. Resource curse theories and empirical studies of this nature typically rely on national statistics to analyse the relationship between resource abundance and growth on the basis of cross-country, comparative studies of growth etc. As Davis and Tilton (2005) argue, while mineral extraction might benefit a nation as a whole, local communities usually bear the costs. It is therefore; appropriate to consider the local scale at which these impacts may occur. Hitherto, most of the research on resource impacts in Nigeria focused on the effects of oil extraction on Niger Delta communities. For example, the works of Watts (2008), UNDP (2006), Amnesty International (2009) and UNEP (2011) are the most comprehensive examples of the analysis of oil extraction and the resulting impact on Niger Delta communities.

This paper, therefore, advocates for the expansion of the resource curse thesis to cover different geographical scales. The focus of studies on communities extends the resource curse thesis by considering local issues that can hinder or help a national economy's ability to manage resources for development. As Davis and Tilton (2005) argue, local communities usually bear the cost of resource extraction. Therefore, measuring the 'resource curse' phenomenon at host-community level would add to the body of knowledge on the local scale of resource curse, as against relying only on country-level measurements as in the work by Auty (1993). Empirical studies and analysis of the communities, together with national studies may show that Nigerian resource curse can be categorised under any of the following propositions: 
- nationally-cursed, locally-cursed;

- nationally-blessed, locally-blessed;

- nationally-cursed, locally-blessed;

- nationally-blessed, locally-curse.

For example, Amnesty International (2009) links decades of oil extraction in the Niger Delta to human rights violations/conflicts on account of environmental damage and pollution. The UNEP (2011) report depicts the devastating effects of long-term oil pollution on the local communities, mainly due to failure in monitoring oil activities. According to UNDP (2006:9), the Niger Delta communities may suffers; "administrative neglect, crumbling social infrastructure and services, high unemployment, social deprivation, abject poverty, filth and squalor, and endemic conflict". These reports, which posits that oil wealth fuels state corruption, profligacy, social crises, economic deprivation and violent civil conflict, it can then be inferred that Nigeria suffers from the curse of its abundant resources from national to local/community level. They also provide the ground for locally based studies in support of the expansion of the resource curse thesis to cover different geographical scales and help identify more detailed gaps in knowledge.

\section{Conclusion}

Evidence suggests that resource-rich countries face the challenges of harnessing mineral revenues to boost development, and that some of those countries suffer from the resource curse. While the literature reviewed here extensively covered the resource-development phenomena, two limitations can be identified in the context of Nigeria: 1) generalisations are based on national issues while the impacts are experienced at the local level; and 2) little attention has been paid to the initial processes of resource development and where the resource is found. This paper calls for the attention of scholars particularly to the latter limitation, in order to add to the body of knowledge on the potential contribution of resources to the Nigerian economy, and their local impacts. Nigeria is currently in the process of expanding and developing its huge non-fuel resources, which will have an adverse impact on existing communities and the environment. The findings could lead to recommendations that can minimise or eliminate resource curse tendencies at the local level. Resources can only contribute to sustainable development when extractions are implemented well, the affected people's rights are preserved, and if the benefits generated from such resources are wellused.

\section{References}

Abubakar, MB 2014, Petroleum Potentials of the Nigerian Benue Trough and Anambra Basin: A Regional Synthesis, Natural Resources, vol. 5, pp. 25.

Ahrend, R 2005, Sustaining growth in a resource-based economy: the main issues and the specific case of Russia, in discussion paper series no. 3, United Nations Economic Commission for Europe, Geneva.

Aldagheiri, MI 2008, Economic diversification in resource abundant economies: the case study of 


\section{M. Chindo et al.}

the minerals industry in Saudi Arabia, PhD Thesis, University of Leicester, UK.

Amnesty International 2009, Nigeria: petroleum, pollution and poverty in the Niger Delta, Amnesty international publications, London.

Auty, RM 1990, Resource based industrialisation: sowing the oil in eight developing countries, Claredon Press, Oxford.

Auty, RM 1993, Sustaining development in minerals economics: the resource curse thesis, Routledge, London.

Auty, RM 1994, Industrial policy reform in six large newly industrialised countries: the resource curse thesis, World Development, vol. 12, pp. 11-26.

Auty, RM 2001a, The political economy of resource-driven growth, European Economic Review, vol. 45, no. 4, pp. 839-846.

Auty, RM 2001b, The political state and the management of mineral rents in capitalsurplus economies: Botswana and Saudi Arabia, Resource Policy, vol. 27, pp. 77-86.

Auty, RM 2004, The political economy of growth collapses in mineral economies, Minerals E Energy - Raw Materials Report, vol. 19, no. 4, pp.3-15.

Ayoade, E 2007, Bitumen resources of Nigeria: status report, Senate Committee on Solid Minerals, Abuja, Nigeria.

Bannon, I \& Collier, P 2003, Natural resources and violent conflict: options and actions, World Bank, Washington DC.

Bhappu, RR \& Guzman, J 1995, Mineral investment decision making, Engineering and Mining Journal, vol. 7, pp. 36-38.

BP (British Petroleum) 2010, BP statistical review of world energy 2010, British Petroleum. London.

Bradshaw, MJ 2005, Population, resources, development and the environment, in $\mathrm{P}$ Daniels et al (eds) An Introduction to Human Geography: Issues for the $21^{\text {st }}$ century, $2^{\text {nd }}$ edn. Section 2.

Bradshaw, MJ 2013, Global energy dilemmas, John Wiley \& Sons.

Brunnschewiler, C \& Bulte, E 2008, The resource curse revisited and revised: a tale of paradoxes and red herrings, Journal of Environmental Economics and Management, vol. 55, pp. 248-264.

Chindo, M \& Bradshaw, MJ 2013, Communities: A Case Study of Oil Sands in Nigeria, in R Dannreuther \& W Ostrowski (eds) 2013 Global Resources: Conflict and Cooperation, ch. 7, pp. 140-158, Palgrave Macmillan, Hampshire.

Costa Lima, GA \& Suslick, SB 2006, Estimating the volatility of mining projects considering price and operating cost uncertainties, Resources Policy, vol. 31, no. 2, pp. 86-94.

Davenport, J 2010, Nigeria aiming to grow mining's GDP contribution to $15 \%$ by 2015 , Mining Weekly, March 15, viewed 20 April 2010, http://bit.ly/hGZL48.

Davis, G \& Tilton, J 2005, The resource curse, Natural Resources Forum, vol. 29, pp. 233242.

Davis, G 1995, Learning to love the Dutch Disease: evidence from the mineral economies, World Development, vol. 23, no. 10, pp. 1765-1779.

Ebohon, SI 2013, State and Rentier Capitalism in Nigeria: The Political Economy of Hydrocarbon Nationalism and Dependence Reproduction, Journal of Third World Studies, vol. 30, no. 1, pp. 209.

Edwik, AA 2007, Oil dependency, economic diversification and development: a case study of Libya, PhD Thesis, University of Salford, UK.

EITI (Extractive Industries Transparency Initiative) 2005, Source book, viewed 14 February 2008, http://eitransparency.org/document/sourcebook.

Esteves, AM 2008, Mining and social development: Refocusing community investment using multi-criteria decision analysis, Resources Policy, vol. 33, no. 1, pp. 39-47. 
Friedland, R 2008, Mining super cycle opportunities to continue into the future, in World Mining Investment Congress, 3-5 June, London, England.

Friedman, T 2006, The first law of petropolitics, Foreign policy, May/June, pp.29.

Hvidt, M 2013, Economic diversification in GCC countries: Past record and future trends, London School of Economics and Political Science (LSE), London.

ICMM (International Council on Mining and Metals) 2007, Good Practice Guidance for Mining and Biodiversity, ICMM, London.

Jensen, N \& Watchenko, L 2004, Resource wealth and political regimes in Africa, Comparative Political Studies, vol. 37, pp. 816- 841.

Ko, V 2014, Nigeria's "Resource Curse", Oil as Impediment to True Federalism. E-International relations students, viewed 27 October 2014, http://www.e-ir.info/2014/07/20/nigeriasresource-curse-oil-as-impediment-to-true-federalism/.

Mahtani, D 2008, The new scramble for Africa's resources, Financial Times Special Report, 28 Jan. pp. 1-6.

McPhail, K 2008, Global governance challenges in industry sectors and supply chains contributing to sustainable development through multi-stakeholder processes: practical steps to avoid the "resource curse", Corporate governance, vol. 8, no. 4, pp. 471-481.

Meyer, R, Attanasi, E \& Freeman, P 2007, Heavy oil and natural bitumen resources in geological basins of the World, US Geological Survey Open-File Report 2007-1084, pp. 336, viewed 10 July 2009, http://pubs.usgs.gov/of/2007/1084/.

Morgan, PG 2002, Mineral title management-the key to attracting foreign mining investment in developing countries?, Applied Earth Science: Transactions of the Institutions of Mining and Metallurgy: Section B, vol. 111, no. 3, pp. 165-170.

Moss, T 2014, How Much Power Does Power Africa Really Need?, viewed 20 February 2014, http://tinyurl.com/q487mpu.

MSMD (Ministry of Solid Minerals Development) 2008, Solid minerals sector: our 34 minerals, MSMD, Abuja.

Müller, M 2010, Revenue transparency to mitigate the resource curse in the Niger Delta? Potential and reality of NEITI, in Bonn International Centre for Conversion (BICC) GmbH, Occasional Paper V. June 2010.

NBS (National Bureau of Statistics) 2010, Revised 2009 and estimates for Q1- Q3, 2010 Gross Domestic Product for Nigeria, NBS Headquarters, Abuja.

NBS (National Bureau of Statistics) 2008, Poverty profile for Nigeria, NBS Headquarters, Abuja.

NBS (National Bureau of Statistics) 2009, Annual abstract of statistics, NBS Headquarters, Abuja.

NBS (National Bureau of Statistics) 2013, Annual abstract of statistics, Abuja: NBS Headquarters.

Nda-Isaiah, S 2013, Nigeria: What Happens in 10 Years When We Hit 250 Million and Oil Sells for \$15?, viewed 9 February 2014, http://tinyurl.com/otx4s5w.

NNPG (Nigerian National Petroleum Corporation) 2014, Development of Nigeria's oil industry, viewed 30 October 2014, http://tinyurl.com/ogklhow.

Obaje, N 2009, Geology and mineral resources of Nigeria, Springer, London.

Obaje, NG, Attah, DO, Opeloye, SA \& Moumouni, A 2006, Geochemical evaluation of the hydrocarbon prospects of sedimentary basins in Northern Nigeria, Geochemical Journal, vol. 40, no. 3, pp. 227-243.

Obaje, NG, Wehner, H, Scheeder, G, Abubakar, MB \& Jauro, A 2004, Hydrocarbon prospectivity of Nigeria's inland basins: From the viewpoint of organic geochemistry and organic petrology, AAPG bulletin, vol. 88, no. 3, pp. 325-353.

ODI (Overseas Development Institute) 2006, Does the Sustained Global Demand for Oil, Gas 
and Minerals Mean That Africa Can Now Fund its Own MDG Financing Gap?' Briefing note 6.

Odularu, GO \& Okonkwo, C 2009, Does energy consumption contribute to economic performance? Empirical evidence from Nigeria, Journal of Economics and International Finance, vol. 1, no. 2, pp. 44-58.

OECD (Organisation for Economic Co-operation and Development)/IEA (International Energy Agency) 2010, Energy poverty: how to make modern energy access universal? International Energy Agency, Paris.

Omeje, K 2006, High Stakes and Stakeholders: Oil Conflict and Security in Nigeria, Aldershot: Ashgate.

Onoh, JK 1983, The Nigerian Oil Economy: from Prosperity to Glut, St Martin's Press, London.

OPEC (Organization of the Petroleum Exporting Countries) 2013, Annual Statistical Bulletin, viewed 23 February 2014, http://tinyurl.com/q8nacfa.

Orogun, PS 2010, Resource control, revenue allocation and petroleum politics in Nigeria: the Niger Delta question, GeoJournal, vol. 75, pp. 459-507.

Palley, T 2006, Combating the natural resource curse with citizen revenue distribution funds: oil and the case of Iraq, Economics for Democratic and Open Societies, Centre for Democratic and Open Societies, Washington DC.

Power, T 2002, Digging to development? A historical look at mining and economic development, Oxfam America, Boston.

Premium Times 2014, Nigeria to increase crude reserves to 40 billion barrels - NNPC, 24 July, 2014.

Research and Markets 2011, Electric Power Sector in Nigeria 2010, viewed 28 February 2011, http://bit.ly/hTkUkt.

Revenue Watch Institute 2010, Countries/Nigeria, transparency snapshot, viewed 10 March 2009, http://bit.ly/icTAJC.

Rosenstein-Rodan, PN 1943, Problems of industrialisation of Eastern and South-Eastern Europe, The Economic Journal, vol. 53, no. 210/2110, pp. 202-211.

Ross, M 2001, Extractive sectors and the poor, An Oxfam America Report, Oxfam America, Boston.

Rosser, A 2006, The political economy of the resource curse: a literature survey. Centre for the future state research programme, viewed 12 October 2008, www.ids.ac.uk/futurestate/.

Rostow, WW 1960, Rostow's stages of development, viewed 22 April 2004, http://bit.ly/f0Oyoh.

Sachs, JD \& Warner, AM 1995, Natural resource abundance and economic growth, NBER Working Paper Series, National Bureau of Economic Research, Cambridge MA.

Sala-i-Martin, X \& Subramanian, A 2003, Addressing the natural resource curse: An illustration from Nigeria (No. w9804), National Bureau of Economic Research.

Sambo, AS 2009, The challenges of sustainable energy development in Nigeria, Nigerian Society of Engineers Forum, 2nd April, 2009, Shehu Yar'Adua Centre, Abuja, Nigeria.

Santos, LR 2010, Macroeconomic aspects in resource-rich countries, PhD Thesis, European University Institute, Italy.

Shamsuddeen, U 2007, Nigeria - Lifting the resource curse, DESTIN public lecture - 11 October 2007, London School of Economics and Political Science (LSE).

Skancke, M 2003, Fiscal policy and petroleum fund management in Norway, in: Davis, J., ed. 2003, Fiscal policy formulation and implementation in oil-producing countries, International Monetary Fund. Ch. 12.

Stevens, P 2003, Resource impact: curse or blessing? A literature survey, Journal of Energy Literature, vol. 9, no. 1, pp. 3-42. 
The Fund for Peace 2014, The Failed States Index 2013, Foreign Policy, Washington DC, viewed 2 March 2014, http://ffp.statesindex.org/nigeria.

Topal, E 2008, Evaluation of a mining project using Discounted Cash Flow analysis, Decision Tree analysis, Monte Carlo Simulation and Real Options using an example, International Journal of Mining and Mineral Engineering, vol. 1, no. 1, pp. 62-76.

UNCTAD (United Nations Conference on Trade and Development) 2007, World investment report 2007: transnational corporations, extractive industries and development, United Nations, New York and Geneva.

UNDP (United Nations Development Programme) 2006, Niger Delta human development report, UNDP, Abuja, Perfect Printer, Lagos.

UNDP (United Nations Development Programme) 2010, Human Development Report: the real wealth of nations: pathways to human development, Palgrave Macmillan for the United Nations Development Programme, New York, pp. 162-191.

UNEP (United Nations Environmental Programme) 2011, Environmental assessment of Ogoniland, United Nations Environment Programme, Nairobi.

UNICEF (United Nations Children's Fund) 2014, Nigeria: Maternal and child health, viewed 29 October 2014,http://www.unicef.org/nigeria/children_1926.html.

USEIA (United States Energy Information Administration) 2009, World proved reserves of oil and natural gas, most recent estimates, Energy Information Administration, Washington DC.

USEIA (United States Energy Information Administration) 2010, International petroleum (Oil) production: OPEC countries crude oil excluding lease condensate, Energy Information Administration, Washington DC.

USEIA (Unites States Energy Information Administration) 2013, International energy outlook 2008, Energy Information Administration, Washington DC.

Vanguard, 2014, FG says oil discovery in Nigerian sedimentary in Chad basin is achievable, 13 March, 2014.

Veit, P, Excell, C \& Zomer A 2011, Avoiding the resource curse: spotlight on oil in Uganda, WRI Working Paper, World Resources Institute, Washington DC.

Warner, M \& Alexander, K 2005, Does the Sustained Global Demand for Oil, Gas and Minerals Mean that Africa Can Now Fund its Own MDG Financing Gap?, Enhancing Economic Performance in the Extractive Industries Sector.

Watts, M (ed) 2008, Curse of the black gold. 50 years of oil in the Niger Delta, Powerhouse Books, New York.

World Bank 2004, Striking a Better Balance- the World Bank Group and Extractive Industries, The final report of the extractive industries review, viewed 15 March 2008, http://bit.ly/hGwBFT.

Wright, G \& Czelusta, J 2002, Resource-based economic growth, past and present, Stanford University, UK. 